\title{
Efektywność wykorzystania środków pomocowych WPR współfinansujących projekty inwestycyjne na przykładzie małych gospodarstw rolnych województwa małopolskiego
}

\section{Effectiveness of CAP Support Funds Used for Co-financing Investment Projects on the Example of Small Farms From the Małopolska Province}

\begin{abstract}
Synopsis: Celem artykułu jest ocena efektywności wykorzystania środków pomocowych WPR współfinansujących projekty inwestycyjne, które realizowane były w latach 2004-2015 przez małe gospodarstwa rolne z województwa małopolskiego. Badania wykazały, że gospodarstwa najczęściej wykorzystywały środki pomocowe na realizację inwestycji polegających na uzupełnianiu i unowocześniana swojego parku maszynowego oraz budowie lub modernizacji obiektów gospodarskich, co doprowadziło do powiększenia zasobów rzeczowych tych gospodarstw, a także unowocześnienia prowadzonej w nich produkcji. Badania wykazały stosunkowo niską efektywność wykorzystania środków pomocowych WPR współfinansujących projekty inwestycyjne. Ponadto stwierdzono istnienie istotnej statystycznie, dodatniej zależności między wielkością gospodarstwa a efektywnością wykorzystania środków.
\end{abstract}

Słowa kluczowe: małe gospodarstwo rolne, efektywność, wspólna polityka rolna

\begin{abstract}
The aim of the paper is to assess the effectiveness of CAP support funds used for co-financing investment projects, which were implemented in the years 2004-2015 by small farms from the Małopolska province in Poland. Studies have shown that the CAP funds supported most often investments for completing and modernizing machinery assets, and construction or modernization of farm buildings. It led to an increase of material resources of these farms, as well as modernization of their production. The research has shown that the effectiveness of using CAP support funds is relatively low. In addition, there is a statistically significant positive correlation between the size of the farm and the efficiency of the use of funds.
\end{abstract}

Key words: small farm, efficiency, common agricultural policy

JEL Classification: Q1, Q12, Q18

\section{Wstęp}

Akcesja Polski do UE spowodowała objęcie polskiego rolnictwa i obszarów wiejskich systemem wsparcia w ramach wspólnej polityki rolnej. Funkcjonowanie gospodarstw rolnych na jednolitym rynku wewnętrznym, a także wdrażanie instrumentów WPR przyczyniło się do zmian w strukturze agrarnej gospodarstw rolnych. Zmiany te miały jednak

\footnotetext{
${ }^{1}$ dr hab., Katedra Polityki Ekonomicznej i Programowania Rozwoju UEK, ul. Rakowicka 27, 31-510 Kraków, e-mail: zmijad@uek.krakow.pl; https://orcid.org/0000-0002-4084-8968
} 
różny kierunek w przekroju poszczególnych grup obszarowych. W Polsce liczebność gospodarstw rolnych jest nadal silnie zróżnicowana terytorialnie i mimo pozytywnych zmian nadal funkcjonuje stosunkowo dużo małych gospodarstw rolnych (Żmija, 2016).

We współczesnej literaturze podział gospodarstw rolnych dokonywany jest według różnych kryteriów, wspólistnieją przy tym różne definicje małego gospodarstwa (Zegar, 2012; Musiał i Drygas, 2013; Wilkin, 2013; Dzun, 2013). W Unii Europejskiej istnieje wiele prób definiowania małego gospodarstwa rolnego, ale pomiędzy krajami członkowskimi czy też sektorami produkcji rolnej występują dość duże różnice, co sprawia, że żadna z definicji nie może zostać uznana za powszechnie stosowaną (Hubbard, 2009; Kostov i Lingard, 2004; Davidova, Fredriksson i Bailey, 2009; What..., 2011).

Najczęściej przyjmuje się, że gospodarstwa małe to takie, które posiadają poniżej 2 lub - w innym ujęciu - poniżej 5 ha użytków rolnych. W 2013 roku w UE funkcjonowało nieco ponad $7 \mathrm{mln}$ gospodarstw rolnych o powierzchni gruntów wykorzystywanych rolniczo poniżej 5 ha, w tym 2 mln gospodarstw poniżej 2 ha. Na obszarze UE występują jednak duże różnice pomiędzy poszczególnymi państwami w liczebności grupy małych gospodarstw rolnych. W 2013 roku gospodarstwa rolne o powierzchni mniejszej niż 5 ha stanowiły $64,7 \%$ wszystkich gospodarstw rolnych w UE. W krajach UE-15 odsetek ten wynosił 45,8\%, podczas gdy w państwach członkowskich, które przystąpiły do UE w 2004, 2007 i 2013 roku, odsetek ten był na poziomie $77,8 \%$ ogółu gospodarstw rolnych. Nowe kraje członkowskie UE charakteryzują się więc zdecydowanie większym rozdrobnieniem gospodarstw. W wartościach bezwzględnych największa liczba małych gospodarstw rolnych do 5 ha w 2013 roku występowała w Rumunii, Polsce, we Włoszech oraz w Grecji. W ujęciu względnym największy odsetek gospodarstw posiadających do 5 ha występował w małych krajach, takich jak Malta oraz Cypr, oraz w Rumunii i Bułgarii (Eurostat, 2016).

Ważnym źródłem finansowania nakładów na inwestycje rzeczowe małych gospodarstw rolnych są środki pieniężne pochodzące z programów pomocowych, które realizowane są w ramach WPR. Mogą być one przeznaczane na różne cele inwestycyjne. W badaniach empirycznych analizowany jest zazwyczaj stopień wykorzystania przez rolników środków pomocowych i kierunki ich rozdysponowania w ramach poszczególnych działań czy programów. W niniejszym opracowaniu zaprezentowano ujęcie, obejmujące w szczególności pomiar efektywności wykorzystania środków pomocowych przyznanych w ramach WPR na realizację projektów inwestycyjnych.

\section{Materiał i metodyka badań}

W badaniach wykorzystano wyniki badań ankietowych, które przeprowadzone zostały w 2016 roku na reprezentatywnej grupie 296 małych gospodarstw rolnych z województwa małopolskiego, zlokalizowanych w 88 różnych gminach. W celu otrzymania próby reprezentatywnej dla populacji małych gospodarstw rolnych zastosowano probabilistyczną (losową) technikę doboru jednostek. Badania empiryczne ograniczono do wybranych instrumentów realizowanych $\mathrm{w}$ ramach WPR, wspierających aktywność inwestycyjną gospodarstw. Wśród badanych działań znalazły się takie jak:

1) „Inwestycje w gospodarstwach rolnych”, „Ułatwienie startu młodym rolnikom”, „Różnicowanie działalności rolniczej i zbliżonej do rolnictwa w celu zapewnienia różnorodności działań lub alternatywnych źródeł dochodu”, „Dostosowanie gospodarstw rolnych do standardów UE”, „Rozwój i ulepszenie infrastruktury 
technicznej związanej z rolnictwem", realizowane w ramach Sektorowego Programu Operacyjnego „Restrukturyzacja i modernizacja sektora żywnościowego i rozwój obszarów wiejskich 2004-2006";

2) „Wspieranie gospodarstw niskotowarowych”, realizowane w ramach Planu Rozwoju Obszarów Wiejskich 2004-2006;

3) „Modernizacja gospodarstw rolnych”, „Różnicowanie w kierunku działalności nierolniczej”, „Tworzenie i rozwój mikroprzedsiębiorstw”, „Ułatwienie startu młodym rolnikom”, „Przywracanie potencjału produkcji rolnej zniszczonego w wyniku wystąpienia klęsk żywiołowych oraz wprowadzenie odpowiednich działań zapobiegawczych”, „Zwiększenie wartości dodanej podstawowej produkcji rolnej i leśnej", realizowane w ramach Programu Rozwoju Obszarów Wiejskich 2007-2013.

Jako małe gospodarstwa rolne uznano takie podmioty, których powierzchnia użytków rolnych na moment przeprowadzania badań wynosiła od 1 do 5 ha użytków rolnych. Przy określaniu małych gospodarstw rolnych zrezygnowano z kryterium ekonomicznego. Przyjęcie takich założeń spowodowało jednak, że w obszarze badań znalazły się również małe, ale specjalistyczne gospodarstwa rolne. Analizując jednak problemy stanu rolnictwa i gospodarstw rolnych w Polsce, należy mieć na względzie przede wszystkim ich zasoby ziemi, ponieważ właśnie one w dużym stopniu aktualnie decydują o możliwościach produkcyjnych i ekonomicznych wielu gospodarstw (Żmija 2016).

Zakres przestrzenny przeprowadzonej analizy obejmował województwo małopolskie, z uwagi na fakt, iż województwo to charakteryzuje się bardzo dużym rozdrobnieniem struktury agrarnej rolnictwa, a podstawowe charakterystyki dotyczące rolnictwa wskazują na gorszą pozycję tego województwa w stosunku do innych części Polski (Żmija 2014).

W celu określenia efektywności wykorzystania środków pomocowych w badaniach wykorzystano wskaźnik przeciętnej prostej stopy zwrotu ${ }^{2}$ o postaci ${ }^{3}$ :

$$
E_{f}=\frac{\overline{\Delta D}}{W}
$$

gdzie:

$\overline{\Delta D}$ - szacowany średni wzrost rocznego dochodu uzyskany dzięki realizacji inwestycji dofinansowanych ze środków WPR,

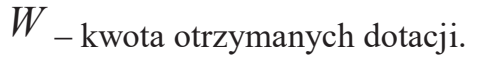

W obrębie zbioru badanych obiektów (gospodarstw rolnych) dokonano podziału gospodarstw rolnych według kryterium efektywności wykorzystania środków pomocowych WPR. Wyznaczono w ten sposób następujące grupy gospodarstw:

I grupa - gospodarstwa o niskiej efektywności wykorzystania środków pomocowych

WPR: $E_{f I}<\bar{E}_{f}$,

\footnotetext{
${ }^{2} \mathrm{~W}$ zależności od przyjętych w liczniku i mianowniku wielkości można obliczyć wiele szczegółowych postaci tego miernika, zob. M. Sierpińska, T. Jachna, Ocena przedsiębiorstwa wedlug standardów światowych, Wydawnictwo Naukowe PWN, Warszawa 2004, s. 339

${ }^{3}$ Zaznaczyć należy, że efektywność inwestycji jest mniejsza od efektywności wykorzystania środków WPR.
} 
II grupa - gospodarstwa rolne o średniej efektywności wykorzystania środków pomocowych WPR: $\bar{E}_{f} \leq E_{f I I}<\bar{E}_{f}+S\left(E_{f}\right)$,

III grupa - gospodarstwa rolne o wysokiej efektywności wykorzystania środków pomocowych WPR: $E_{f I I I} \geq \bar{E}_{f}+S\left(E_{f}\right)$,

gdzie: $\overline{E_{f}}, S\left(E_{f}\right)$ oznaczają odpowiednio średnią arytmetyczną i odchylenie standardowe wartości wskaźnika efektywności.

$\mathrm{W}$ toku przeprowadzonych badań określono również zależności między poziomem efektywności wykorzystania środków pomocowych a wybranymi cechami rolników oraz ich gospodarstw. W tym celu wykorzystano test niezależności $\chi^{2}$.

\section{Wyniki badań}

W badanej próbie większość rolników była płci męskiej (blisko 80\% respondentów), a najliczniejszą grupą wiekową były osoby powyżej 40 roku życia (blisko 73\% respondentów). Spośród badanych najliczniejszą grupę stanowiły osoby, które miały wykształcenie średnie zawodowe (nieco ponad 34\%) oraz wyższe (prawie 30\%). Połowa rolników posiadała wykształcenie rolnicze. Wśród badanych dominowały osoby posiadające długi staż w prowadzeniu gospodarstwa rolnego - blisko $95 \%$ badanych wskazało, że prowadzi swoje gospodarstwo rolne dłużej niż 10 lat. Duża część respondentów twierdziła, że mają następców do prowadzenia gospodarstwa rolnego.

W badanej grupie gospodarstw rolnych najliczniejszą grupę stanowiły te gospodarstwa, które posiadały powierzchnię mieszczącą się w przedziale $4-5$ ha użytków rolnych, ich udział w badanej próbie wynosił nieco ponad 56\%. Najmniejszy udział miały gospodarstwa o powierzchni użytków rolnych w przedziale $1-2$ ha (nieco ponad 5\%). Największą przeciętną wielkością użytków rolnych (powyżej 4 ha) charakteryzowały się gospodarstwa rolne znajdujące się na terenie powiatu miechowskiego, nowotarskiego, dąbrowskiego, proszowickiego, limanowskiego oraz krakowskiego. Z kolei najmniejsza przeciętna wielkość gospodarstwa cechuje powiat wielicki, chrzanowski oraz tatrzański. Badane gospodarstwa rolne charakteryzowały się bardzo dużym rozdrobnieniem działek wchodzących w skład gospodarstwa, a większość badanych rolników (95\%) gospodarowała wyłącznie na własnych gruntach.

Prawie wszystkie gospodarstwa rolne prowadziły produkcję roślinną, a wśród dominujących rodzajów produkcji respondenci wymieniali najczęściej zboża, warzywa gruntowe oraz uprawy pod osłonami. Tylko $27 \%$ badanych prowadziło chów zwierząt, najczęściej bydła mlecznego, trzody chlewnej oraz bydła rzeźnego. W badanych gospodarstwach wśród zasobów pracy dominowała rodzinna siła robocza.

W latach 2004-2015 badane małe gospodarstwa rolne z województwa małopolskiego zrealizowały w ramach rozpatrywanych działań inwestycyjnych projekty o wartości blisko $75,8 \mathrm{mln}$ zł (rys. 1). Kwota pomocy, która została przyznana w ramach tych projektów, wyniosła nieco ponad $37,4 \mathrm{mln}$ zł. W sumie największe nakłady inwestycyjne poniesiono w ramach działania „Modernizacja gospodarstw rolnych” oraz działania „Różnicowanie w kierunku działalności nierolniczej”, które realizowane były w ramach PROW 2007-2013. 
Łączna wartość tych nakładów wyniosła nieco ponad $54 \mathrm{mln}$ zł, co stanowiło ponad 71\% wartości wszystkich badanych projektów.

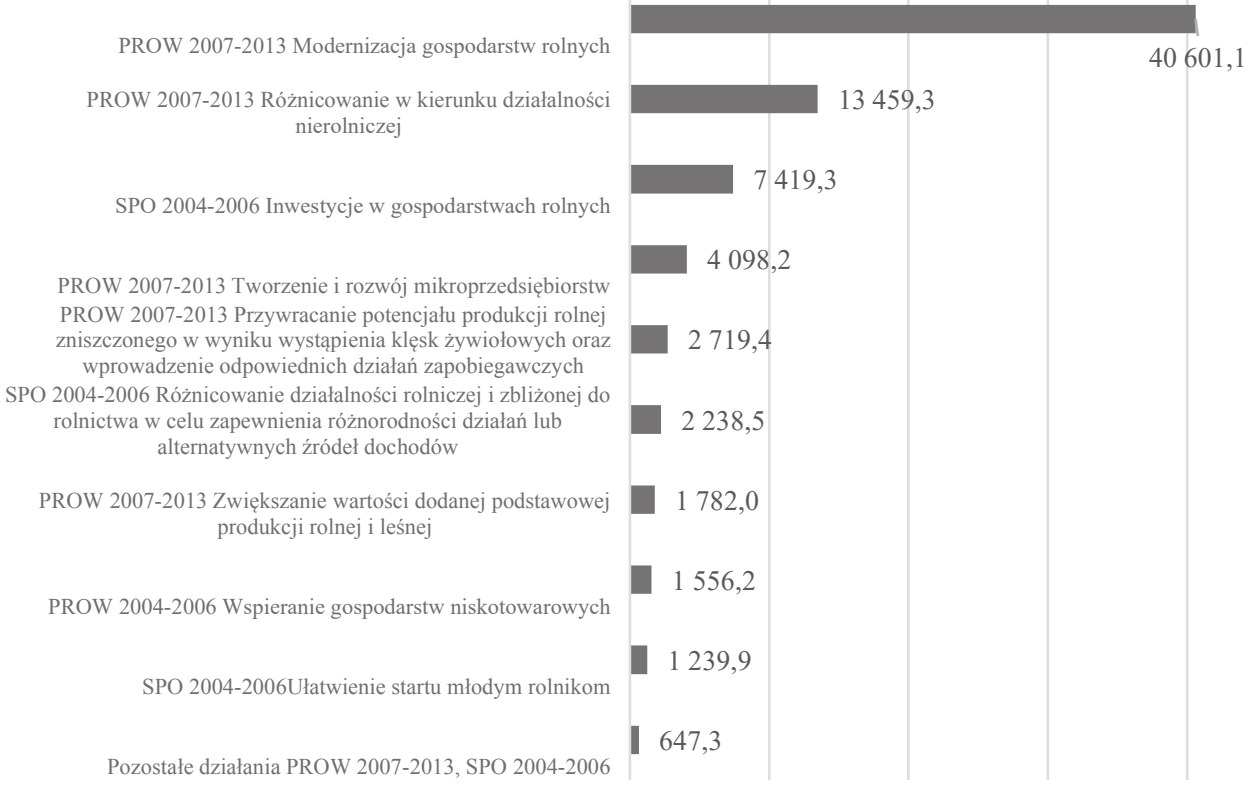

Rys. 1. Wartość projektów inwestycyjnych zrealizowanych w latach 2004-2015 przez badane gospodarstwa rolne (w tys. zł) według działań realizowanych w ramach WPR

Fig. 1. The value of investment projects implemented from 2004-2015 by examined farms (in thousands PLN) according to measures implemented under the CAP

Źródło: opracowanie własne na podstawie przeprowadzonych badań.

Analizując strukturę nakładów inwestycyjnych można zauważyć, że w okresie objętym badaniem rolnicy przeznaczali środki pomocowe przede wszystkim na zakup maszyn, urządzeń, narzędzi i wyposażenia. Tego typu nakłady stanowiły blisko 64\% ogólnej wartości nakładów inwestycyjnych poniesionych w ramach zrealizowanych projektów (rys. 2). Prawie $1 / 4$ nakładów inwestycyjnych przeznaczona została na budowę lub modernizację obiektów gospodarskich. Do pozostałych kategorii nakładów, które miały stosunkowo mniejsze znaczenie dla badanych gospodarstw rolnych, zaliczyć należy m.in. wydatki na zagospodarowanie terenu wokół gospodarstwa, na inwestycje związane z agroturystyką czy zakup ziemi lub zwierząt.

Efektywność wykorzystania środków pomocowych WPR współfinansujących projekty inwestycyjne małych gospodarstw rolnych obliczona została jako iloraz szacowanego przez rolników średniego wzrostu rocznego dochodu uzyskanego dzięki realizacji inwestycji dofinansowywanych ze środków WPR do kwoty otrzymanych dotacji inwestycyjnych. Wartość tego wskaźnika była podstawą podziału badanych gospodarstw rolnych na trzy grupy (rys. 3). 


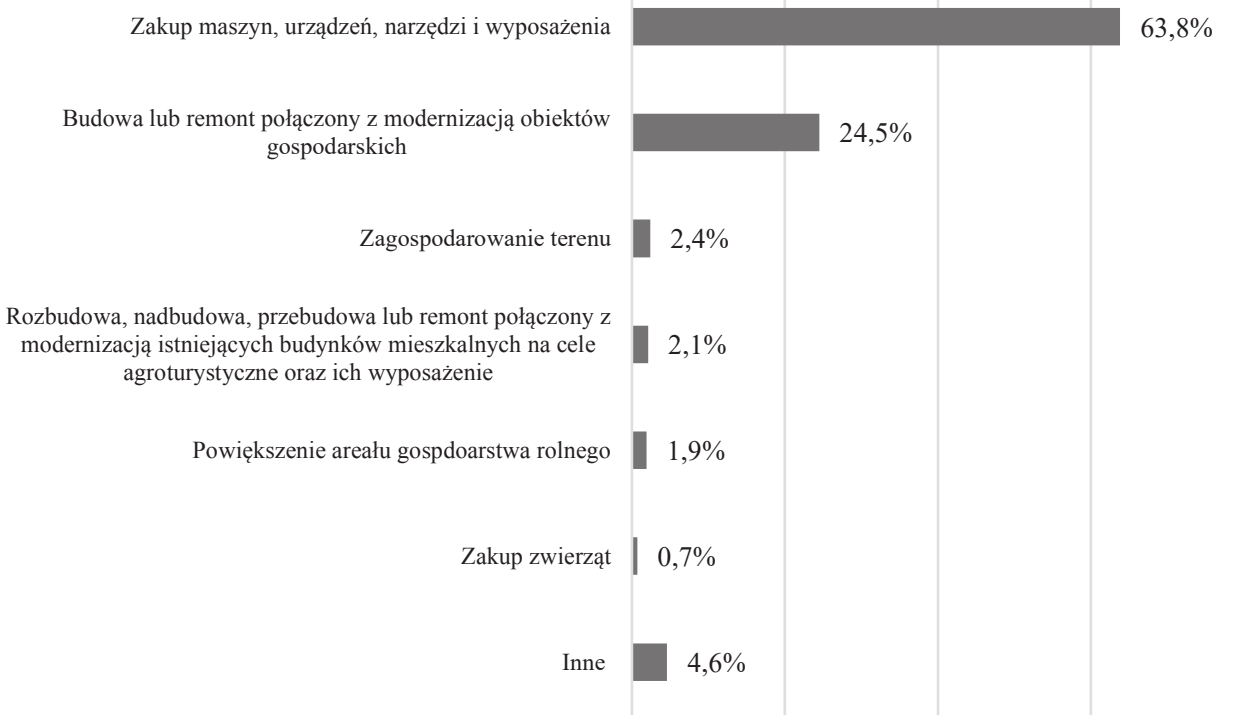

Rys. 2. Struktura nakładów inwestycyjnych według kategorii nakładów

Fig. 2. The structure of investment outlays by category of expenditures

Źródło: opracowanie własne na podstawie przeprowadzonych badań.

Wśród badanych gospodarstw rolnych najwięcej bo aż $65,2 \%$ ogółu, zostało zakwalifikowanych do grupy gospodarstw, które w badanym okresie osiągały niską efektywność wykorzystania środków pomocowych WPR współfinansujących projekty inwestycyjne. Prosta stopa zwrotu $\mathrm{z}$ tych inwestycji kształtowała się w przedziale od $0,0 \%$ do 2,4\%. Przeciętna efektywność w tej grupie gospodarstw rolnych wynosiła 1,0\%, a mediana - 1,7 \%. Dużo mniej liczną grupą gospodarstw były te, które osiągnęły prostą stopę zwrotu w przedziale od 2,4\% do 5,1\%. Zostały one zaliczone do grupy gospodarstw, które w badanym okresie osiągały średnią efektywność wykorzystania środków pomocowych WPR. Przeciętna efektywność środków pomocowych przeznaczanych na projekty inwestycyjne wyniosła w tej grupie 3,5\%, a mediana -3,3\%. Najmniej liczną grupa gospodarstw były natomiast te, które osiągnęły wysoką efektywność wykorzystania środków pomocowych, tj. wynoszącą przynajmniej 5,1\%. Przeciętna efektywność w tej grupie wynosiła $9,1 \%$, zaś mediana $-7,0 \%$.

W celu zbadania zależności pomiędzy poziomem efektywności wykorzystania środków pomocowych WPR współfinansujących projekty inwestycyjne badanych gospodarstw rolnych a wybranymi charakterystykami rolników oraz ich gospodarstw zastosowano test niezależności $\chi^{2}$. W badaniach przyjęto poziom istotności na poziomie $\alpha=0,05$. 


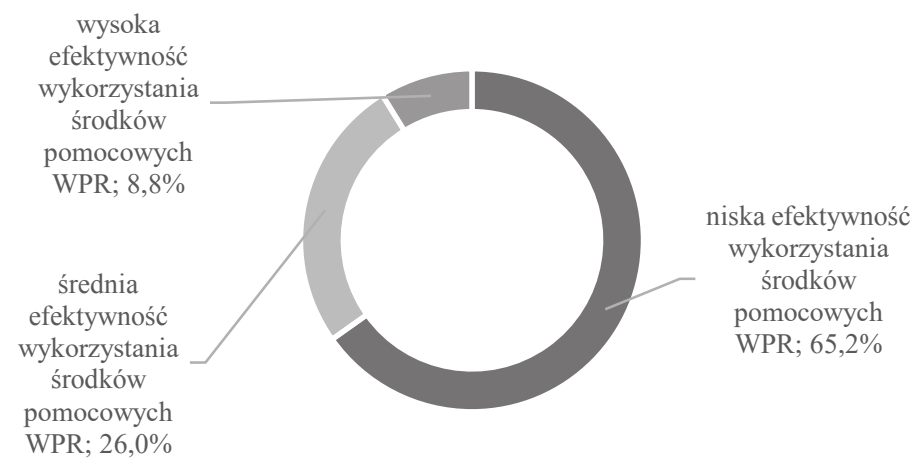

Rys. 3. Struktura badanych gospodarstw rolnych według poziomu efektywności wykorzystania środków pomocowych WPR współfinansujących projekty inwestycyjne

Fig. 3. The structure of the researched farms according to the level of effectiveness of CAP support funds used for co-financing investment projects

Źródło: opracowanie własne na podstawie przeprowadzonych badań.

W wyniku przeprowadzonych badań nie stwierdzono zależności pomiędzy poziomem efektywności wykorzystania środków pomocowych WPR współfinansujących projekty inwestycyjne badanych gospodarstw rolnych, a wiekiem i wykształceniem właściciela gospodarstwa rolnego czy lokalizacją gospodarstwa. Stwierdzono natomiast, że występuje istotna statystycznie zależność poziomu efektywności wykorzystania środków, które współfinansują projekty inwestycyjne małych gospodarstw rolnych, od powierzchni gospodarstwa.

\section{Wnioski}

Badania przeprowadzone $\mathrm{w}$ grupie małych gospodarstw rolnych $\mathrm{z}$ województwa małopolskiego wykazały, że wykorzystywały one środki pochodzące z WPR przede wszystkim na realizację inwestycji polegających na uzupełnieniu i unowocześnieniu swojego parku maszynowego oraz budowie lub modernizacji obiektów gospodarskich. Tego typu inwestycje doprowadziły do powiększenia zasobów rzeczowych tych gospodarstw, a także unowocześnienia prowadzonej w nich produkcji. Na uwagę zasługuje fakt, że inwestycje w stosunkowo małym stopniu dotyczyły powiększania areału gospodarstw, co wynikać może z przesłanek takich, jak brak możliwości jej zakupu w sąsiedztwie gospodarstwa lub też bardzo wysokich cen gruntów. Sytuacja taka nie jest korzystna, zwłaszcza w warunkach dużego rozdrobnienia agrarnego gospodarstw rolnych, jakie występuje w województwie małopolskim.

Na podstawie wyników przeprowadzonych badań można stwierdzić, że efektywność wykorzystania środków pomocowych WPR współfinansujących projekty inwestycyjne małych gospodarstw rolnych jest raczej niska. Istotną przyczyną, która uniemożliwia osiąganie wyższych efektów finansowych ze zrealizowanych inwestycji są ograniczone 
zasoby pozostałych czynników produkcji, przede wszystkim ziemi. Zbyt mała powierzchnia gospodarstwa rolnego uniemożliwia efektywne wykorzystanie kapitału rzeczowego, powiększonego dzięki pozyskanym środkom. W toku przeprowadzonych badań potwierdzono występowanie dodatniej zależności pomiędzy efektywnością wykorzystania środków pomocowych ze WPR, współfinansujących projekty inwestycyjne, a powierzchnią użytków rolnych gospodarstwa. Małe gospodarstwa rolne o większej powierzchni użytków rolnych posiadają większy potencjał produkcyjny. Daje im to większe możliwości bardziej efektywnego wykorzystania zasobów, powiększonych w wyniku zrealizowanych w gospodarstwie inwestycji.

\section{Literatura}

Davidova, S., Fredriksson, L., Bailey, A. (2009). Subsistence and Semi-subsistence Farming. School of Economics Discussion Papers, University of Kent.

Dzun, W. (2013). Drobne gospodarstwa w rolnictwie polskim. Próba definicji i charakterystyki (Polish agricultures' small farms: an effort to define this category and its characteristics). Wieś i Rolnictwo, 2, 9-27.

Eurostat (2016), Small and large farms in the EU - statistics from the farm structure survey.

Hubbard, C. (2009). Small farms in the EU, how small is small? 111th EAAE-IAAE Seminar Small Farms: Decline or Persistence. 26-27 June 2009. University Kent, Canterbury.

Kostov, P., Lingard, J. (2004). Subsistence Agriculture in Transition Economies: Its Roles and Determinants. Journal of Agricultural Economics, 55(3), 565-579.

Musiał, W. Drygas, M. (2013). Dylematy procesu delimitacji drobnych gospodarstw rolnych (Dilemmas of the proces of delimitation of small farms), Wieś $i$ Rolnictwo, 2, 55-74

Sierpińska, M., Jachna, T. (2004). Ocena przedsiębiorstwa według standardów światowych (Evaluation of the enterprise according to global standards), Wydawnictwo Naukowe PWN, Warszawa.

What is a small farm? (2011). EU Agricultural Economic Briefs, No 2 - July 2011.

Wilkin, J. (2013). Aksjologia i prakseologia polityki wobec drobnych gospodarstw rolnych w Polsce i Unii Europejskiej (Axiology and praxeology of policy towards small farms in Poland and the European Union), Wieś i Rolnictwo, 2, 43-54

Zegar, J.S. (2012). Współczesne wyzwania rolnictwa (Contemporary agriculture challenges), Wydawnictwo Naukowe PWN, Warszawa.

Żmija, D. (2016). Wpływ wspólnej polityki rolnej Unii Europejskiej na funkcjonowanie małych gospodarstw rolnych (The impact of the common agricultural policy of the European Union on the functioning of small farms), Wydawnictwo Difin, Warszawa.

Żmija, K. (2014). Rozwój przedsiębiorczości na obszarach wiejskich przy wykorzystaniu środków Unii Europejskiej (Development of entrepreneurship in rural areas with the use of European Union funds). Prace Naukowe Uniwersytetu Ekonomicznego we Wrocławiu, 360, 253-261.

Do cytowania / For citation:

Żmija D. (2018). Efektywność wykorzystania środków pomocowych WPR współfinansujących projekty inwestycyjne na przykładzie małych gospodarstw rolnych województwa małopolskiego. Problemy Rolnictwa Światowego, 18(2), 334-341; DOI: 10.22630/PRS.2018.18.2.60

Żmija D. (2018). Effectiveness of CAP Support Funds Used for Co-financing Investment Projects on the Example of Small Farms From the Małopolska Province (in Polish). Problems of World Agriculture, 18(2), 334-341; DOI: 10.22630/PRS.2018.18.2.60 